\title{
Omezená právní osobnost pobočného spolku a její důsledky
}

\section{Limited Legal Personality of Subordinate Associations and its Consequences}

\author{
Luboš Brim*
}

\begin{abstract}
Abstrakt
Občanský zákonik umožnuje zakládáni pobočných spolkì, ježjsou právnickými osobami, avšak jejichž právni subjektivita je odvozena od subjektivity blavního spolku a mưže byit stanovami blavního spolku omezena. Následujici článek rozebirá predpoklady a dìsledky takovébo omezeni pro hmotnèprávni a procesní jednáni pobočnébo spolku, jakož i problematiku aplikovatelnosti pravidel o omežené právní osobnosti pobočných spolku na odborové organizace založené jinými odborovými organizacemi, jejichž status byl modifikován (a żnejasnèn) zákonem č. 460/2016 Sb.
\end{abstract}

\section{Klíčová slova}

Omezená právni osobnost; pobočné spolky; právní jednání; neplatnost.

\section{Abstract}

The Civil Code allows for establishment of subordinate associations which are legal entities whose legal personality is derived from the personality of the main association and can be limited by a provision in the statutes of the main association. The following treatise analyses the preconditions and the consequences of such limitation for substantive and procedural acts of subordinate associations and deals with the topic of applicability of the rules pertaining to limited legal personality of subordinate associations on labour unions founded by other labour unions, whose status has been modified (and made unclear) by Act No. 460/2016 Coll.

\section{Keywords}

Limited Legal Personality; Subordinate Associations; Juridical Acts; Invalidity.

\section{Úvod}

Právní osobností či právní subjektivitou ${ }^{1}$ se rozumí právním řádem přiznaná schopnost mít práva a povinnosti. ${ }^{2}$ Nositeli právní subjektivity jsou jednak osoby fyzické, jednak

\footnotetext{
* Mgr. Bc. Luboš Brim, doktorand, Katedra Občanského práva, Právnická fakulta, Masarykova univerzita, Brno / Ph.D. student, Department of Civil Law, Faculty of Law, Masaryk University, Brno, Czech Republic / E-mail: lubos.brim@gmail.com

1 Pojmy „právní osobnost“ a „právní subjektivita“ používám v následujícím textu jako synonyma.

2 Viz $\ 15$ obč. zák. Dále srovnej HURDÍK, Jan. In: ŠVESTKA, Jiřía a kol. Občanské zákonike. Komentár. Svazeek I. Praha: Wolters Kluwer, 2014, s. 77; PELIKÁNOVÁ, Irena. In: ČERNÁ, Stanislava, Ivana ŠTENGLOVÁ, Irena PELIKÁNOVÁ a kol. Právo obchodních korporací. Praha: Wolters Kluwer, 2015, s. 21; či MUZIKÁŘ, Martin. In: PETROV, Jan, Michal VÝTISK, Vladimír BERAN a kol. Občanský zákoník. Komentár. Praha, 2017, s. 53; Viz též PELIKÁN, Robert. Prámni subjektivita. Praha: Wolters Kluwer, 2012, s. 52.
} 
osoby právnické [S 18 zákona č. 89/2012 Sb., občanského zákoníku (dále jen „obč. zák.")]. Právnické osoby mohou podle \ 20 odst. 1, věty druhé, obč. zák. bez zřetele na předmět své činnosti mít práva a povinnosti, které se slučují s jejich právní povahou. České soukromé právo je tedy vybudováno na zásadě generální subjektivity právnických osob, jíž lze rozumět právě tuto principiální způsobilost právnických osob nést práva a povinnosti slučitelné s jejich podstatou. ${ }^{3}$ Zákon se však může od zásady generální subjektivity odchýlit a právní osobnost určitých kategorií právnických osob zúžit. ${ }^{4} \mathrm{~V}$ těchto př́padech je pak namístě hovořit o omezené či speciální subjektivitě právnické osoby., Právní řád bývá konfrontován s př́pady, v nichž určitá právní skutečnost, zpravidla právní jednání, jevově směruje k založení práv a povinností entity, která právním subjektem není, a k níž se tudíž práva a povinnosti nemohou připínat. Podobné situace jsou vcelku uspokojivě řešitelné, poněvadž občanský zákoník nabízí východisko ve svém \ 17 odst. 2: non-subjektu, k němuž byly právní následky formálně směřovány, právo ani povinnost vzniknout nemůže, často však lze nalézt relevantní subjekt, do jehož

3 Takto viz např́iklad ZOULÍK, František. In: DVOŘÁK, Jan, Jiří ŠVESTKA, Michaela ZUKLÍNOVÁ a kol. Občanské právo bmotné. Svazek 1. Díl první: obecná část. Praha: Wolters Kluwer, 2013, s. 265; PELIKÁNOVÁ, Irena. In: ČERNÁ, Stanislava, Ivana ŠTENGLOVÁ, Irena PELIKÁNOVÁ a kol. Právo obchodních korporací. Praha: Wolters Kluwer, 2015, s. 43-44; a DOBROZEMSKÝ, Václav a Jan STEJSKAL. Nevýdělečné organizace v teorii. 2. vyd. Praha: Wolters Kluwer, 2016, s. 31.

4 Činí tak např́klad u společenství vlastníků jednotek, srovnej \ 1195 obč. zák. a NOVOTNÝ, Marek. In: SPÁČIL, Jiří a kol. Občanský zákoník III. Věcná práva (』 976-1474). Komentár. Praha: C. H. Beck, 2013, s. 765 .

5 Bylo by možné zvolit také odlišnou definici užitých pojmů a konstatovat, že právní osobnost právnické osoby je vždy speciální právě proto, že právnické osoby nemohou nabývat veškerá práva a povinnosti a že jsou nutně vyloučeny z účasti na řadě právních poměrů (kupř́ikladu většině vztahư rodinněprávních); k tomu srovnej zejména HURDÍK, Jan. Právnické osoby a jejich typologie. 2. vyd. Praha: C. H. Beck, 2009, s. 59-60. Je jistě myslitelné vymezit generální právní subjektivitu jako způsobilost mít veškerá práva či povinnosti a následně tuto vlastnost upírat právnickým osobám se zdůvodněním, že jsou vyloučeny z práv a povinností, které se mohou připínat toliko k osobám fyzickým. Při akceptaci právě uvedené definice nepochybně platí, že právnické osoby generální subjektivity nepožívají. V tomtéž významu však zřejmě nejsou nadány generální subjektivitou ani osoby fyzické, nebot' existují též práva, jejichž nositeli mohou být toliko osoby právnické (např́iklad ta, jež se odvijejí od jejich vnitřní strukturovanosti, jako jsou práva korporace vưči jejím členům). Účelnějším se tudíž jeví definovat generální subjektivitu coby označení pro principiální způsobilost právnických osob nabývat práva a povinnosti slučitelné s jejich podstatou, a naopak o speciální (omezené, zúžené) právní subjektivitě mluvit tam, kde určité právnické osoby jsou (respektive mohou být) na základě zvláštního ustanovení zákona či stanov dále limitovány v tom, jaká práva, respektive povinnosti smějí nabývat a nést.

6 Na poněkud odlišných principech spočívá postavení osob veřejného práva. Byt' se podle $\int 20$ odst. 2 obč. zák. i na tyto subjekty použijí ustanovení občanského zákoníku, je-li to slučitelné s jejich právní povahou, přednostně se jejich právní status spravuje zvláštními zákony, podle nichž byly zř́zeny. V teorii se pak při pojednávání o subjektivitě veřejnoprávních korporací uvádí, že „ve veřejném právu máme co činit s tzv. principem speciality, resp. principem omezené subjektivity, které vycházejí z toho, že postačí tolik právní subjektivity, kolik je jí třeba k tomu, aby byly pokryty sledované účely (zájmy) členů, nikoli však ty zájmy členů, které korporace nesleduje. Co v soukromém právu platí jako výjimka, to ve veřejném právu se považuje za běžný jev.“ (HENDRYCH, Dušan. In: HENDRYCH, Dušan a kol. Správní právo: obecná ćást. 9. vyd. Praha: C. H. Beck, 2016, s. 69). 
právní sféry se mají účinky podle povahy věci promítnout, dokonce i se zachováním platnosti př́slušného právního jednání. ${ }^{7}$ Existence entity s limitovanou právní osobností se z tohoto hlediska ukazuje paradoxně problematičtější. Omezený rozsah subjektivity naznačuje, že se jedná o právní subjekt pouze ve vztahu k určitým právům a povinnostem, v jiných aspektech je naopak non-subjektem. Hodnocení následků právního jednání, jež z mezí právní osobnosti subjektu toliko částečně právně existujícího vybočuje, je pak méně jednoznačné.

\section{Omezená právní osobnost pobočného spolku a její důsledky pro právní jednání}

Jedním z typů právnických osob, jejichž právní osobnost může podléhat omezením, je pobočný spolek. V jeho př́padě však tato limitace nevyplývá př́mo ze zákona (jako je tomu u naprosté většiny jiných právnických osob, jimž je speciálně odňata možnost nabývat určitá práva nebo povinnosti), nýbrž - potenciálně - ze stanov hlavního spolku, jenž rozhodl o jeho založení. Pobočný spolek je totiž koncipován jako subjekt, jehož osobnost je pouhým derivátem osobnosti spolku hlavního (\228 odst. 1, věta první, obč. zák.). ${ }^{8}$ Zákon zde pouze propůjčuje omezení subjektivity pobočného spolku zakotvenému ve stanovách spolku hlavního účinky erga omnes, aniž by právní osobnosti dané korporace sám stanovoval hranice. Z hlediska teoretického jde tedy o statutární omezení subjektivity. ${ }^{9}$ Potřeba ochrany právního postavení třetích osob pak vyvolává nutnost zajistit publicitu omezení právní subjektivity skrze veřejný rejstř́k, což se promítá do \ 29 odst. 2 písm. b) zákona č. 304/2013 Sb., o veřejných rejstř́icích právnických a fyzických osob a o evidenci svěřenských fondů (dále jen ,zákon o veřejných rejstř́icích“), v souladu s nímž se do spolkového rejstříku o pobočném spolku zapíše také rozsah jeho způsobilosti mít a nabývat práva či povinnosti podle stanov hlavního spolku. ${ }^{10}$

7 Srovnej HURDÍK, Jan. In: ŠVESTKA, Jiří a kol. Občanský quakoník. Komentár. Svazek I. Praha: Wolters Kluwer, 2014, s. 88: „Na rozdil od predchozi právni praxe, kedy nedostatek v postaveni osoby fyzické nebo právnické vedl k patovým situacím založeným na konstatováni nedostatku postaveni osoby jako osoby v práunim smyslu, fakticky qúcastnèné na právnich vątazich bez dalšich konsekvenci, občanský zákoník reši nedostatek postaveni osoby prictenim práva nebo povinnosti existujici osobè. O kterou osobu se jedná, je rèseno podle kritéria povaby právního prípadu. Take napr. bude-li právnè jednat fyzická osoba jménem neexistujici právnické osoby, pričtou se následky tohoto jednáni této jednajici fyzické osobé, o jejiž projev ville jako clověka ve skutečnosti jde."

8 Srovnej KULOGLIJA PODIVÍNOVÁ, Martina. In: Petr LAVICKÝ a kol. Občanský zákoník I. Obecná cást (』 1-654). Komentár. Praha: C. H. Beck, 2014, s. 1141; či BERAN, Karel a Jiří JANÁK. Mưže pobočný spolek vystoupit z hlavního spolku? Právni roz̧hledy, 2018, č. 17, s. 598.

9 Srovnej HURDÍK, Jan. Právnické osoby a jejich typologie. 2. vyd. Praha: C. H. Beck, 2009, s. 62-63.

10 Citované ustanovení doslova říká, že se do spolkového rejstř́ku o pobočném spolku zapíše „rozsah jeho práv a povinností podle stanov blavního spolku ". Tuto formulaci je však třeba chápat jako legislativně-technické pochybení a její nedostatky se patří překlenout výkladem, nebot’ jistě nebylo zamýšleno zakotvit požadavek, aby byla do spolkového rejstř́ku zapisována jednotlivá práva pobočného spolku, nýbrž rozsah jeho způsobilosti tato práva mít a nabývat ve smyslu \228 obč. zák. 
Lze si povšimnout, že v tomto ani jiném právním předpisu není normy, jež by jednoznačně regulovala důsledky absence údaje o rozsahu právní subjektivity ve stanovách či veřejném rejstř́ku. Znění \228 odst. 1 obč. zák. a \29 odst. 2 písm. b) zákona o veřejných rejstřících by snad mohlo nasvědčovat mínění, že má-li být pobočný spolek v jakékoli míre nadán způsobilostí $\mathrm{k}$ právưm a povinnostem, potažmo k jejich nabývání, musí tak být řečeno ve stanovách hlavního spolku a odpovídající údaj musí být zapsán do veřejného rejstř́ku. ${ }^{11}$ Především z pragmatických důvodů je však nutné preferovat výklad opačný, dle něhož není-li ve stanovách zakotveno a v rejstř́íku zapsáno omezení právní subjektivity, je osobnost pobočného spolku generální. Naprostá většina v současnosti existujících pobočných spolků, zejména těch, jež vznikly transformací organizačních jednotek občanských sdružení [viz \ 6 odst. 2 písm. e) zákona č. 83/1990 Sb. o sdružování občanů (dále jen „zákon o sdružování občanư(), a \ 3045 odst. 2 obč. zák.], nemá ve spolkovém rejstříku zapsán žádný údaj o rozsahu právní subjektivity. Pakliže by byla zvolena interpretace, dle níž je k existenci jakékoli právní osobnosti pobočného spolku nutný zápis informace o jejím rozsahu do veřejného rejstř́k u, byla by účast většiny pobočných spolků na právním životě znemožněna, což by se jevilo jako nepřiměřený zásah do dosud neproblematizovaného zpo̊sobu fungování spolkové sféry, který zákonodárce zjevně učinit nezamýšlel. ${ }^{12}$ Nadto je zjevné, že požadavek na zápis rozsahu subjektivity pobočného spolku do veřejného rejstř́k ku slouží $\mathrm{k}$ tomu, aby osoby se spolkem jednající nebyly překvapeny navenek obtížně zjistitelnou limitací právní osobnosti jejich protějšku, v důsledku níž by smlouva, kterou se spolkem uzavřely, trpěla vadou. Naopak trvání na tom, aby bylo ve stanovách a spolkovém rejstříku výslovně uvedeno, že pobočný spolek požívá plné právní subjektivity, by bylo pouhou samoúčelnou formálností, jež by nesloužila žádnému hospodářskému cíli. Také tento teleologický důvod tedy nasvědčuje závěru, že zakotveno ve stanovách a zapsáno ve spolkovém rejstř́ku musí být omezení právní subjektivity pobočného spolku, nikoli pozitivní vymezení jeho osobnosti jako generální. ${ }^{13}$

Ještě pozoruhodnější je neexistence normy, jež by reglementovala dopady vykročení z mezí právní osobnosti. Naskýtá se tak široká škála potenciálních řešení tohoto problému. Variantu, dle níž by omezení právní subjektivity pobočného spolku ve stanovách byly připisovány pouze interní účinky, čemuž by zdánlivě mohla nasvědčovat i slova

11 Takto patrně soudí ŠTEFKO, Martin. Aplikuje se \228 odst. 1 ObčZ na základní odborové organizace? Právni roẓbledy, 2015, č. 7, s. 246.

12 Podle \3045 odst. 2 obč. zák. se k zachování právní osobnosti organizačních jednotek občanských sdružení transformovaných na pobočné spolky vyžadovalo toliko podání návrhu na jejich zápis do spolkového rejstř́k Tato fakticita založila důvěru spolků v řádnost uvedeného postupu a nabyla tím normativní rozměr.

13 K závěru o nutnosti aplikovat obecné pravidlo o generální subjektivitě právnických osob zakotvené v \ 20 odst. 1, větě druhé, obč. zák. v př́padě, že ze stanov hlavního spolku nelze dovodit omezení osobnosti spolku pobočného, se přiklání též HRABÁNEK, Dušan. In: PETROV, Jan, Michal VÝTISK, Vladimír BERAN a kol. Občanský zákoník. Komentár. Praha, 2017, s. 290. 
důvodové zprávy, ${ }^{14}$ se patří odmítnout, nebot' při zvolení této interpretace by pravidlo obsažené v \228 odst. 1, větě druhé, obč. zák. postrádalo normativní význam (interní meze působení pobočného spolku by si totiž hlavní spolek mohl stanovit i bez podobného zákonného ustanovenî). Je naopak nutné vycházet z teze, že smysl předmětné úpravy spočívá v přiznání externích účinků statutárnímu omezení osobnosti pobočného spolku, prričemž k odvrácení neblahých dopadů na osoby stojící vně slouží zajištění publicity tohoto omezení skrze veřejný rejstř́k. ${ }^{15}$ Ostatně, pokud by omezení subjektivity mělo dopad výlučně do vnitřních poměrů pobočného spolku (v tom smyslu, že by bylo možné volat k odpovědnosti členy orgánů, kteří by při jednání za pobočný spolek překročili stanovené hranice jeho subjektivity), bylo by zbytečné trvat na zpř́stupnění údaje o rozsahu právní osobnosti prostřednictvím veřejného rejstř́íku.

Správnější je proto usuzovat, že zákon v \228 odst. 1 obč. zák. rozšiřuje účinky toho, co by bylo jinak jen vnitřním ujednáním právnické osoby, na všechny právní subjekty. ${ }^{16}$ Byl-li v odborné literatuře vysloven názor opačný (dle něhož vybočením z mezí právní subjektivity statutárním orgánem pobočného spolku není dotčena platnost právního jednání, jež za danou právnickou osobu tento orgán učinil, nanejvýše je tím založena povinnost jednajícího člena orgánu $\mathrm{k}$ náhradě vzniklé škody), a to s odkazem na rozsudek Nejvyššího soudu ze dne 31. 5. 2011, sp. zn. 29 Cdo 382/2010, ${ }^{17}$ je nezbytné zdůraznit, že uvedený judikát pojednával (v kontextu zákona o sdružování občanů) o problematice (nepřípustného) omezení jednatelského oprávnění statutárního orgánu organizační jednotky občanského sdružení, nikoli o omezení její způsobilosti k právům a povinnostem. Důsledky omezení způsobilosti k právům a povinnostem v něm blíže analyzovány nebyly, přesto lze však v odůvodnění nalézt zmínku, dle níž by jedině z právě takovéhoto omezení právní subjektivity mohla vyplynout erga omnes působící limitace oprávnění statutárního orgánu organizační jednotky vystupovat jejím jménem navenek. ${ }^{18}$

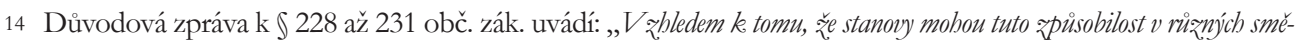

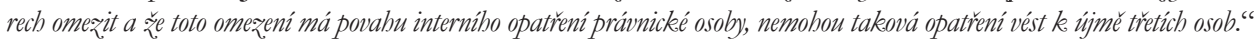

15 Má-li být právní osobnost pobočného spolku omezena s účinky navenek, musí být kumulativně splněny obě podmínky předvídané $\int 228$ odst. 1, větou druhou, obč. zák., limitovaný rozsah způsobilosti mít práva a povinnosti tedy musí být zakotven ve stanovách hlavního spolku a údaj o těchto stanovami daných mezích musí být zapsán ve veřejném rejstř́ku. Ve stanovách obsažené, ale řádně nezapsané omezení subjektivity by mohlo vyvolávat účinky uvnitř spolku, avšak nemohlo by působit vůči osobám stojícím vně spolku (právní osobnost pobočného spolku by tak v tomto případě zůstávala generálnî).

16 Podobně viz též HRABÁNEK, Dušan. In: PETROV, Jan, Michal VÝTISK, Vladimír BERAN a kol. Občanský zákoník. Komentár. Praha, 2017, s. 291.

17 DOBROZEMSKÝ, Václav a Jan STEJSKAL. Nevýdělećné organizace v teorii. 2. vyd. Praha: Wolters Kluwer, 2016, s. 165; shodně DOBROZEMSKÝ, Václav. Právní postavení pobočného spolku. Úǔetnictvi neziskového sektoru, 2017, č. 9, s. 8.

18 Rozsudek Nejvyššího soudu ze dne 31. 5. 2011, sp. zn. 29 Cdo 382/2010 (uveřejněný ve Sbírce soudních rozhodnutí a stanovisek pod č. 139/2011): „K pojmovým znakưm statutárního orgánu patrú $i$ to, že rozsah oprávnèni statutárního orgánu jednat jménem právnické osoby je neomezený (ve vǐech věcech). Omezeni jednatelskébo oprávnèní statutárního orgánu by mohlo být dìsledkem omezeni zpuisobilosti právnické osoby nabývat práva a povinnosti..." 
Citované rozhodnutí tedy nejenže nevyvrací závěr o externích účincích omezené subjektivity pobočného spolku, ale dokonce jej naopak podporuje.

Odmítneme-li možnost, že omezení osobnosti pobočného spolku nevyvolává žádných účinků navenek, je třeba přijmout závěr, v souladu s nímž je důsledkem překročení mezí subjektivity určitý defekt právních jednání takto učiněných. Při řešení problému, jak tuto vadu právního jednání pojmenovat a klasifikovat, se lze inspirovat způsoby, jimiž se teorie a praxe s prrípady excesu z hranic limitované právní subjektivity vyrovnávala a vyrovnává u jiných právnických osob. Takto zjistíme, že v případě socialistických organizací podléhajících režimu zákona č. 109/1964 Sb., hospodářského zákoníku (které v souladu s \18 tohoto předpisu ve znění účinném do 30.4 1990 mohly nabývat práv a zavazovat se, jen pokud to nebylo v rozporu s plněním jejich společenských úkolù ${ }^{19}$ ), společenství vlastníků jednotek [coby osob se způsobilostí k právům a povinnostem omezenou ze zákona, srovnej \ 9 odst. 1 zákona č. 72/1994 Sb., kterým se upravují některé spoluvlastnické vztahy $\mathrm{k}$ budovám a některé vlastnické vztahy $\mathrm{k}$ bytům a nebytovým prostorům a doplňují některé zákony (zákon o vlastnictví bytů), a \1195 obč. zák.] i právnických osob vstoupivších do likvidace (u nichž přinejmenším část teorie dovozuje zúžení právní subjektivity právnické osoby na jednání směřující k naplnění cíle likvidace, ${ }^{20}$ srovnej \ 196 obč. zák.) se v literatuře jako o důsledku vybočení z mezí limitované subjektivity hovořilo o nicotnosti právního úkonu, potažmo právního jednání. ${ }^{21}$

Operují-li popsané konstrukce s konceptem nicotnosti (nulity) právního úkonu či jednání, je třeba si položit otázku, jak podřadit jejich závěry pojmům platného práva. Z hlediska právního stavu účinného od 1.1.2014 by jako o nepř́ihodnějším ekvivalentu pojmu nicotnosti bylo možné uvažovat o zdánlivosti. ${ }^{22,23}$ Zákon ovšem následek v podobě

19 Jejich koncepce byla tedy vybudována na základě doktríny ultra vires (srovnej RONOVSKÁ, Kateřina. In: FIALA, Josef, Milan KINDL a kol. Občanský zákoník. Komentár. I. díl. Praha: Wolters Kluwer, 2009, s. 106).

20 ČECH, Petr a Petr ŠUK. Právo obchodnich korporaci v praxi a pro praxi (nejen soudní). Praha: Bova Polygon, 2016, s. 66.

21 Tento závěr ohledně společenství vlastníků jednotek vyslovují FIALA, Josef. In: NOVOTNÝ, Marek, Josef FIALA, Tomáš HORÁK, Jaroslav OEHM a Josef HOLEJŠOVSKÝ. Zákon o vlastnictví bytũ. 4. vyd. Praha: C. H. Beck, 2011, s. 104; a NOVOTNÝ, Marek. In: NOVOTNÝ, Marek, Tomáš HORÁK, Josef HOLEJŠOVSKÝ a Jaroslav OEHM. Bytové spoluvlastnictví a bytová drušstva. Praha: C. H. Beck, 2016, s. 159; ohledně právnických osob v likvidaci PELIKÁN, Robert. In: ČERNÁ, Stanislava, Ivana ŠTENGLOVÁ, Irena PELIKÁNOVÁ a kol. Právo obchodních korporací. Praha: Wolters Kluwer, 2015, s. 242; JOSKOVÁ, Lucie. Likvidátor a statutární orgán kapitálové společnosti v likvidaci. Obchodnéprávní revue, 2017, č. 3, s. 70; a JOSKOVÁ, Lucie. In: JOSKOVÁ, Lucie, Markéta PRAVDOVÁ a Lenka ZACHARDOVÁ. Likvidace obchodnich společností. Praha: C. H. Beck, 2017, s. 51; a ohledně socialistických organizací PELIKÁNOVÁ, Irena. Komentár k obchodnímu zákoníku. 2. díl. Praha: Linde, 1998, s. 28.

22 K ekvivalenci těchto pojmů se kloní např́íklad TICHÝ, Luboš. In: ŠVESTKA, Jiří a kol. Občanský qákoník: komentár. Svazek I. Praha: Wolters Kluwer, 2014, s. 1338; i HANDLAR, Jiří. In: LAVICKÝ, Petr a kol. Občanský zákoník I. Obecná část (』 1-654). Komentár. Praha: C. H. Beck, 2014, s. 1965 a násl.

23 Př́mo ve vztahu $\mathrm{k}$ pobočným spolkům závěr o zdánlivosti excedujícího právního jednání vyslovuje HRABÁNEK, Dušan. In: PETROV, Jan, Michal VÝTISK, Vladimír BERAN a kol. Občanský qákoník. Komentár. Praha, 2017, s. 291. 
zdánlivosti právního jednání na deficit subjektivity výslovně neváže. Bylo by možné konstruovat jej pouze teoreticky na základě teze, že zdánlivost se pojí s př́pady, kdy nejsou splněny pojmové znaky právního jednání. ${ }^{24}$ Subjektivita jednajícího se však zpravidla řadí mezi náležitosti právního jednání, nikoli mezi jeho pojmové znaky. ${ }^{25}$ Nadto je zdánlivost, respektive nicotnost, ve vlastním smyslu namístě vnímat především jako důsledek faktického (kauzálního) stavu, spočívajícího v absenci projevu vůle, ${ }^{26}$ nikoli jako nedostatek normativní kvality, jímž ovšem deficit právní osobnosti, jež je nevyhnutelně normativním znakem, ${ }^{27}$ být musí.

Konstrukci o zdánlivosti jednání mimo rámec subjektivity pobočného spolku by bylo myslitelné odvíjet od tvrzení, že zde chybí vůle jednajícího (\551 obč. zák.). Domnívám se ale, že takové pojetí je problematizováno skutečností, že fyzická osoba vystupující jménem pobočného spolku jako jeho zástupce fakticky vưli projevuje (a směřuje tak k nahrazení vưle pobočného spolku ve smyslu \ 151 odst. 1 obč. zák.); projev vưle zde tedy coby jev kauzálního světa existuje. Ze zúžení právní osobnosti pobočného spolku podle \228 obč. zák. přitom vyplývá následek normativní, totiž že takto zástupce za právní spolek jednat nesmí, nikoli následek faktický v podobě neexistence projevené vưle. Jednání jménem pobočného spolku v mezích jeho právní subjektivity a mimo ně se liší právě tím, že v jednom případě spadá do rozsahu způsobilosti $\mathrm{k}$ právům a povinnostem vymezeného ve stanovách hlavního spolku a zapsaného ve veřejném rejstř́ku, zatímco ve druhém případě nikoli. Z tohoto hlediska bych nepokládal za opodstatněné existenci za pobočný spolek projevené vưle v prve zmíněné situaci uznávat a ve druhé popírat s důsledkem v podobě použití kategorie zdánlivého právního jednání. Označení jednání jménem pobočného spolku mimo meze jeho právní osobnosti za zdánlivé by nicméně v naznačeném kontextu nevyvolávalo podstatně odlišné praktické důsledky od dovození absolutní neplatnosti tohoto právního jednání; i prŕklon k variantě zdánlivosti je prritom argumentačně obhajitelný.

Př́padnějším se mi však přesto jeví vyvozovat z nedostatku právní osobnosti neplatnost právního jednání. Shledáváme-li pak právní jednání překračující hranice subjektivity

24 MELZER, Filip. In: MELZER, Filip, Petr TÉGL a kol. Občanský zákoník: velký komentár. Svazek III. Praha: Leges, 2014, s. 572. Zákonodárce mưže zdánlivost výslovně navázat i na jiné nedostatky než absenci pojmových znaků právního úkonu (srovnej MELZER, Filip. Otazníky kolem vzdání se práva na náhradu škody. Bulletin advokacie, 2018, č. 5, s. 17), to arci v případě překročení mezí právní subjektivity pobočného spolku neučinil.

25 KNAPP, Viktor a Štefan LUBY. Ceskoslovenské občanské právo. Svazek I. Praha: Orbis, 1974, s. 112-116 a 133-134; FIALA, Josef. In: FIALA, Josef a kol. Občanské právo hmotné. 3. vyd. Brno: Masarykova univerzita, 2002, s. 25-28 a 34-35; HANDLAR, Jiří. In: LAVICKÝ, Petr a kol. Občanský zákoník I. Obecná cást (』 1-654). Komentár. Praha: C. H. Beck, 2014, s. 1941-1944; a BERAN, Vladimír. In: PETROV, Jan, Michal VÝTISK, Vladimír BERAN a kol. Občanský zákoník. Komentár. Praha, 2017, s. 582.

26 RUBAN, Radek a Pavel KOUKAL. Několik poznámek k otázce nicotnosti v občanském právu. Právní roz̧hledy, 2011, č. 23 , s. 857.

27 Srovnej RUBAN, Radek. K právní subjektivitě, povaze a jednání právnických osob. Časopis pro právni vědu a praxi, 2013, roč. 21, č. 3, s. 390. Dostupné z: https://journals.muni.cz/cpvp/article/view/5703 
pobočného spolku neplatným, je namístě volit neplatnost absolutní, spíše než relativní. Důvodem je jednak teoretická intuice, dle níž je právní subjektivita nutným předpokladem vzniku práv a povinností v právní sféře dotčené osoby. Nelze tolerovat, aby non-subjekt (přičemž pobočný spolek v rozsahu překračujícím rámec jeho specializované subjektivity non-subjektem je) účinně nabýval práv, jestliže se nikdo tohoto defektu nedovolá. Je tu však rovněž zcela praktický aspekt - omezení subjektivity je nástrojem, pomocí něhož si hlavní spolek ex ante vytváří limity pưsobení pobočných spolků, jež jsou, jak již bylo shora naznačeno, pouhými deriváty jeho vlastní právní existence. Jeví se nezbytné, aby se hlavní spolek mohl spolehnout na to, že akty překračující jím nastavená (a řádně zveřejněná) omezení, nebudou vyvolávat právních účinků, aniž by musel provádět neustálou kontrolu právních jednání pobočných spolků (k jejíž realizaci ostatně nemusí mít dostatečně účinné prostředky) a následně se pokoušet zpochybňovat platnost aktů vykračujících z mezí jejich právní subjektivity. Jednání za hranicemi subjektivity pobočného spolku by proto mělo být hodnoceno jako odporující zákonu ${ }^{28}$ a zjevně narušující veřejný pořádek ve smyslu \588 obč. zák., jelikož norma vyplývající z \228 odst. 1 obč. zák. má statusový charakter (je součástí úpravy „postaveni““ právnických osob), a představuje tak pravidlo chránící veřejný pořádek. ${ }^{29,30}$

Lze se též setkat s myšlenkou, že by excedující jednání činěná jménem pobočného spolku měla být posuzována podobně jako překročení hranic svéprávnosti a stíhána absolutní neplatností. ${ }^{31}$ Koncept svéprávnosti právnické osoby je od účinnosti zákona

28 Konkrétně normě implicitně obsažené v \ 228 odst. 1, větě druhé, obč. zák., dle níž pobočný spolek nesmí mít a nabývat práva mimo hranice subjektivity, jež vyplývají ze stanov hlavního spolku a jež jsou zapsány ve veřejném rejstř́ku.

29 K tomu viz usnesení Nejvyššího soudu ze dne 31. 10. 2017, sp. zn. 29 Cdo 387/2016, uveřejněné ve Sbírce soudních rozhodnutí a stanovisek pod č. 10/2019.

30 Již citovaný NOVOTNÝ, Marek. In: NOVOTNÝ, Marek, Tomáš HORÁK, Josef HOLEJŠOVSKÝ a Jaroslav OEHM. Bytové spoluvlastnictvi a bytová družstva. Praha: C. H. Beck, 2016, s. 159, sice při překročení mezí právní osobnosti společenství vlastníků jednotek v teoretické rovině hovoří o nicotnosti, v pojmech platné právní úpravy však důsledek vybočení z hranic subjektivity pojmenovává jako absolutní neplatnost podle \39 zákona č. 40/1964 Sb., respektive nyní podle \580 a \588 obč. zák. Též u socialistických organizací podléhajících režimu hospodářského zákoníku se v doktríně povětšinou prosazoval názor, že jednání mimo hranice způsobilosti k právům a povinnostem působilo absolutní neplatnost dotčeného právního úkonu pro rozpor se zákonem (srovnej STUNA, Stanislav a kol. Hospodárské právo. Praha: Orbis, 1966, s. 143; DUŠÁNEK, František a kol. Hospodář́ký qákoník. Komentár. Praha: Panorama, 1986, s. 56; a ZÁDĚRA, Filip. Ohlédnutí nad pojmem „obchodní společnost“. Časopis pro právní vědu a praxi, 2015, č. 2, s. 170. Dostupné z: https://journals.muni.cz/cpvp/article/view/5322).

31 DVOŘÁK, Tomáš. In: ŠVESTKA, Jiř́ a kol. Občanský quákonik: komentár. Svazek I. Praha: Wolters Kluwer, 2014, s. 688. Podobně judikatura přistupuje v režimu právní úpravy účinné do 31. 12. $2013 \mathrm{k}$ právním úkonům společenství vlastníků jednotek, vybočujícím z mezí jejich speciální právní subjektivity, nebot' dovozuje, že rozsah způsobilosti těchto osob k právním úkonům je koextenzivní s jejich limitovanou subjektivitou, pročež je úkon překračující meze zpo̊sobilosti k právům současně zatížen nedostatkem způsobilosti k právním úkonům a stíhá jej neplatnost dle $\int 38$ zákona č. 40/1964 Sb. (viz např. rozsudek Nejvyššího soudu ze dne 16. 6. 2015, sp. zn. 26 Cdo 811/2015, a rozsudek Nejvyššího soudu ze dne 12. 12. 2017, sp. zn. 26 Cdo 801/2017). 
č. 89/2012 Sb. sporný. V doktríně převažuje názor, podle něhož právnické osoby, jež mohou např́ště jednat toliko prostřednictvím zástupců, svéprávností nadány nejsou, ${ }^{32}$ Petr Čech ovšem vybízí k opatrnosti ve vyslovování obecných závěrů ohledně dané otázky s tím, že úsudek o svéprávnosti právnických osob či jejím nedostatku v našem právním řádu by měl být utvořen až na základě analýzy a abstrakce z konkrétních pravidel, jež se daného problému dotýkají. ${ }^{33}$ At’ tak či onak, chápeme-li aplikaci \581 obč. zák., regulujícího následky jednání nesvéprávného, na právnické osoby s limitovanou subjektivitou jako toliko analogické použití dané normy, nemělo by být vyloučeno ani za předpokladu, že pojem svéprávnosti právnické osoby odmítneme. Důsledkem překročení mezí právní osobnosti by pak i při použití této konstrukce měla být absolutní neplatnost. Argumenty, jimiž je zdůvodňováno traktování neplatnosti podle \581 obč. zák. jako absolutní v př́padě překročení mezí svéprávnosti nezletilým či osobou ve svéprávnosti omezenou, ${ }^{34}$ u pobočných spolku sice použít nelze, jsou zde však jiné (výše zmíněné) důvody, pro něž by vyslovení neplatnosti právních jednání překračujících meze zvláštní subjektivity nemělo být závislé na námitce dotčených osob.

K př́istupu dovozujícímu (absolutnî) neplatnost právních jednání vybočujících z limitované subjektivity pobočného spolku existuje alternativa, kterou by bylo lze považovat za konformnější s principem in favorem negotii. Již při aplikaci právní úpravy účinné do 31. 12. 2013 čerpala judikatura ${ }^{35}$ inspiraci z německé doktríny, v níž jednání jménem neexistující právnické osoby není nutně zatíženo neplatností, nýbrž zakládá závazek na straně samotného jednajícího, podobně jako by tomu mohlo být v př́padě nezmocněného jednatele vystupujícího bez náležitého oprávnění jménem existující osoby. ${ }^{36,37}$

32 Viz HURDÍK, Jan. In: ŠVESTKA, Jiří a kol. Občanský zákoník: komentár. Svazek I. Praha: Wolters Kluwer, 2014, s. 81-82; MELZER, Filip. In: MELZER, Filip, Petr TÉGL a kol. Občanský zákoník - velký komentár. Svazek I. Praha: Leges, 2013, s. 256; NOVOTNÁ KRTOUŠOVÁ, Lucie. Následky konfliktu zájmů člena statutárního orgánu právnické osoby jako zástupce a právnické osoby jako zastoupeného. Právní roz̧bledy, 2016, č. 17, s. 588; DVOŘÁK, Bohumil. K problematice procesního jednání právnických osob. Právní roz̧bledy, 2016, č. 19, s. 649; a BERAN, Karel. Může být právnická osoba svéprávná? Právník, 2018, č. 8, s. 657-669; respektive BERAN, Karel. In: BERAN, Karel a kol. Právní jednáni a odpovédnost právnických osob po rekodifikaci českého soukromého práva. Praha: Wolters Kluwer, 2018, s. 21-38.

33 ČECH, Petr. Ke svéprávnosti právnické osoby a postavení člena statutárního orgánu při jednání za ni (nejen) v situaci zájmového střetu. Právní roz̧hledy, 2016, č. 23-24, s. 835.

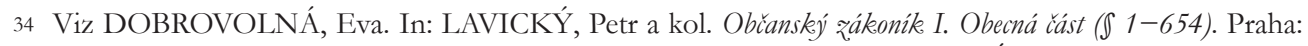
C. H. Beck, 2014, s. 2093-2094; a MELZER, Filip. In: MELZER, Filip, Petr TÉGL a kol. Občanský zákonik: velký komentár. Svazeke III. Praha: Leges, 2014, s. 743.

35 Rozsudek Nejvyššího soudu ze dne 5. 8. 2009, sp. zn. 28 Cdo 292/2009.

36 HEINRICHS, Helmut. In: PALANDT, Otto. Bürgerliches Geseţ̧uch. 66. vyd. München: C. H. Beck, 2007, s. 187; či rozsudky německého Spolkového soudního dvora ze dne 8. 7. 1974, sp. zn. II ZR 180/72, ze dne 20. 10. 1988, sp. zn. VII ZR 219/87, či ze dne 12. 11. 2008, sp. zn. VIII ZR 170/07.

37 Naznačená konstrukce vede k závěru, že bude z jednání jménem neexistující právnické osoby zavázán sám jednající, což bude zpravidla odpovídat výsledkům aplikace pravidla regulujícího následky jednání jménem non-subjektu, jež je nyní zakotveno v \17 odst. 2 obč. zák. 
Ani toto řešení však není bez obtíží. Aplikací úpravy nezmocněného jednatelství na př́ipad vystupování jménem pobočného spolku nad rámec jeho subjektivity bychom dospěli k závěru, že by při excesu vznikl právní poměr mezi adresátem právního jednání a kuprríkladu členy statutárního orgánu pobočného spolku či jinými osobami, jež za pobočný spolek jednaly. Byla-li by osoba, s níž bylo jednáno, v dobré víre, mohla by v souladu s \440 odst. 2 obč. zák. požadovat na zavázaných zástupcích pobočného spolku, aby splnili právním jednáním převzaté povinnosti, případně nahradili vzniklou škodu. Otázkou však zůstává, jaká práva a povinnosti by měl adresát vybočujícího právního jednání, který by v dobré víre nebyl. ${ }^{38}$

Mám za to, že z \440 odst. 2, věty druhé, obč. zák. vyplývá, že není-li protistrana v dobré víre ohledně ráádnosti jednání jménem zastoupené osoby, nemá ani právo na splnění toho, co bylo ujednáno, proti zástupci, ani právo na náhradu škody. I v těchto situacích se ale uplatní věta první \440 odst. 2 obč. zák., jejíž použití dobrou vírou adresáta právního jednání podmíněno není a z níž vyplývá, že je jednající osoba „zavázána sama“. Tato vázanost jednajícího nezakládá v prípadě nedostatku dobré víry smluvního protějšku povinnost splnit, co bylo ujednáno, ani povinnost nahradit vzniklou škodu, ale má význam pro určení ochuzeného a obohaceného, bylo-li na základě takto učiněného právního jednání poskytnuto plnění, které má být vypořádáno v režimu bezdůvodného obohacení. ${ }^{39}$ Povinnost vydat majetkový prospěch by v př́padě plnění podle takovéto smlouvy zásadně stíhala jednajícího zástupce samotného. Naproti tomu pobočnému spolku by z právního jednání, jež bylo uskutečněno za hranicemi jeho právní osobnosti, podle $\int 440$ obč. zák. neměly vzejít práva ani povinnosti (toto právní jednání by pobočný spolek nemohl by ani schválit, jako je to možné v klasických prrípadech nezmocněného jednatelství, nebot's hranicemi své vlastní právní osobnosti není pobočný spolek oprávněn disponovat), proto by jej v zásadě ani nestíhala povinnost $\mathrm{k}$ vydání bezdůvodného obohacení vzniklého plněním na základě právního jednání, z něhož nebyl zavázán on,

$38 \mathrm{~V}$ daném kontextu přitom můžeme očekávat, že adresátům právních jednání zpravidla dobrou víru ohledně toho, že zástupce jedná v mezích právní osobnosti pobočného spolku, možné přičítat nebude, nebot' omezení subjektivity pobočného spolku musí být zapsáno ve veřejném rejstř́ku, jinak nevyvolává vưči třetím osobám žádné účinky.

39 V kontextu zákona č. 40/1964 Sb. viz výklad důsledků plnění na základě smlouvy uzavřené nezmocněným jednatelem a ani dodatečně neschválené v rozsudcích Nejvyššího soudu ze dne 1. 6. 2017, sp. zn. 28 Cdo 3232/2016, ze dne 11. 7. 2017, sp. zn. 28 Cdo 4673/2016, a ze dne 26. 3. 2019, sp. zn. 27 Cdo $4056 / 2017$. 
nýbrž zástupce (restituční povinnost pobočného spolku coby osoby neúčastné na řečeném právním jednání by mohla být založena toliko za podmínek $\int 2995$ obč. zák. $\left.{ }^{40}\right){ }^{41}$

Konstrukce připodobňující postavení osoby jednající mimo rámec osobnosti pobočného spolku k pozici nezmocněného jednatele tak sice má jistou přitažlivost, protože za předpokladu dobré víry protistrany ${ }^{42}$ umožňuje zachovat platnost právního jednání vykračujícího z mezí právní subjektivity dané právnické osoby, ${ }^{43}$ může však vést ke konsekvencím, které jsou kontraintuitivní a pro subjekty soukromoprávního styku nejspíše obtížně srozumitelné. Situování zástupce pobočného spolku do pozice protějšku osoby, jež zamýšlela jednat se spolkem samotným, by patrně nekorespondovalo s intencemi zúčastněných subjektů, a tento nedostatek převyšuje př́nos vyplývající z potenciálního udržení platnosti učiněného právního jednání.

Za správné proto pokládám přijetí závěru, že překročení mezí limitované právní subjektivity pobočného spolku má za následek absolutní neplatnost tohoto právního jednání, přičemž právní následky vyplývající z této neplatnosti (povinnost vydat bezdůvodné obohacení vzniklé plněním podle daného právního jednání, či naopak oprávnění požadovat jeho vydánî) zásadně stíhají pobočný spolek samotný.

Zmínky zasluhuje též několik dalších dílčích problémů, jež se pojí s omezenou osobností pobočného spolku.

40 K výkladu \ 2995 obč. zák. blíže srovnej PETROV, Jan. In: HULMÁK, Milan a kol. Občanský zákoník

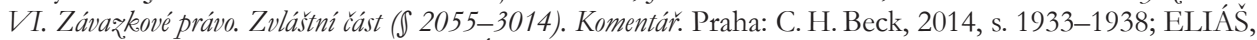
Jan, Luboš BRIM a Hana ADAMOVÁ. Bezdivodné obohacení. Praha: Wolters Kluwer, 2016, s. 91-94; MELZER, Filip a Kristián CSACH. In: MELZER, Filip, Petr TÉGL a kol. Občanský zákoník: velký komen-

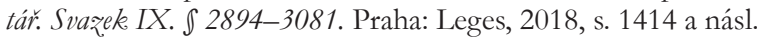

41 Jak přiléhavě poukázal recenzent tohoto textu, pakliže by zastoupení pobočného spolku statutárním orgánem bylo klasifikováno jako smluvní zastoupení [k diskusi nad povahou zastoupení právnické osoby členem jejího orgánu viz např. HAVEL, Bohumil. Konflikt zájmů při správě obchodních korporací (vztah \ 437 odst. 2 ObčZ a 54 a násl. ZOK). Právni roz̧ledy, 2015, č. 8, s. 272; NOVOTNÁ KRTOUŠOVÁ, Lucie. Následky konfliktu zájmů člena statutárního orgánu právnické osoby jako zástupce a právnické osoby jako zastoupeného. Právni roz̧hledy, 2016, č. 17, s. 588; nebo ČECH, Petr a Petr ŠUK. Právo obchodnich korporaci v praxi a pro praxi (nejen soudní). Praha: Bova Polygon, 2016, s. 17-23]; bylo by na prrípady excesu zapotřebí přednostně aplikovat $\int 446$ obč. zák., jenž zakládá nevyvratitelnou domněnku schválení překročení zástupčího oprávnění v případě, že zmocnitel bez zbytečného odkladu poté, co se o právním jednání dozvěděl, neoznámí osobě, se kterou zástupce jednal, svůj nesouhlas. Domnívám se nicméně, že ani použitím pravidel o smluvním zastoupení by se na řešení problému důsledků překročení mezí subjektivity pobočného spolku nic podstatného nezměnilo, poněvadž schválení excesu z mezí právní osobnosti nepokládám za možné (ani skrze nevyvratitelnou domněnku ve smyslu $\int 446$ obč. zák.), přičemž důsledky neschváleného excesu zástupce se i u smluvního zastoupení spravují subsidiárně aplikovaným $\int 440$ obč. zák. [obdobně srovnej DÁVID, Radovan a Miloslav HRDLIČKA. In: LAVICKÝ, Petr a kol. Občanský zákoník I. Obecná část (』 1-654). Komentár. Praha: C. H. Beck, 2014, s. 1673].

42 Jenž je ovšem s ohledem na materiální publicitu spolkového rejstř́ḱ málo pravděpodobný.

43 Důsledkem nedostatku zmocnění není totiž neplatnost dotčeného právního jednání, nýbrž pouze to, že osobu, jejíž jménem jednající vystupoval, učiněné právní jednání neváže (viz např. rozsudky Nejvyššího soudu ze dne 29. 8. 2007, sp. zn. 29 Odo 1635/2005, ze dne 20. 4. 2017, sp. zn. 21 Cdo 2494/2016, a ze dne 11. 7. 2017, sp. zn. 28 Cdo 4673/2016). Tentýž závěr by se musel prosadit i při přiměřené aplikaci pravidel o nezmocněném jednatelství na jednání jménem neexistující právnické osoby či mimo meze limitované subjektivity právnické osoby. 


\section{Omezení způsobilosti pobočného spolku mít povinnosti z deliktů}

Dosud provedený výklad se zabýval omezením subjektivity z hlediska právních jednání, kam jistě bude v praxi limitace rozsahu zpơsobilosti pobočného spolku mít práva a povinnosti téměř vždy směřovat. Přinejmenším teoreticky nicméně vyvstává i otázka, zdali je myslitelné, aby hlavní spolek omezil též způsobilost pobočného spolku mít a nabývat povinnosti z deliktů (respektive ji vymezil jinak než jako zpơsobilost plnou). Mám za to, že nikoli. Zatímco při kontraktaci coby konsensuálním utváření právních poměrů lze po osobách vystupujících v občanskoprávním styku požadovat, aby ověrovaly, zda pobočný spolek jedná v mezích své právní osobnosti (jejîž zúžení mủže být legitimním nástrojem formování spolkové struktury), v prípadě deliktů jsou práva a povinnosti zakládána nedobrovolně a poškozeným nemůže být príčítáno k tíži, vznikla-li jim újma při činnosti vyloučené hlavním spolkem z rozsahu subjektivity spolku pobočného. Ujednání stanov, v němž by se promítala snaha redukovat způsobilost pobočného spolku nést a nabývat povinnosti vyplývající z deliktů, by tedy (ač by se formálně opíralo o text \228 odst. 1, věty druhé, obč. zák.) mělo být shledáno absolutně neplatným pro rozpor se zákonem a veřejným pořádkem, př́padně pro zjevný rozpor s dobrými mravy (\580 a \588 obč. zák.).

\section{Omezení procesní subjektivity pobočného spolku}

Zaměřovali-li jsme zatím pozornost na problematiku hmotněprávní, je třeba prozkoumat také důsledky omezené právní osobnosti pobočných spolků v rovině procesního práva. Zákon č. 99/1963 Sb., občanský soudní řád, ve znění pozdějších předpisů (dále jen „o. s. r..“), v \ 19 procesní subjektivitu navazuje na existenci právní osobnosti ve smyslu hmotného práva. ${ }^{44}$ Způsobilost být účastníkem řízení je přitom procesní podmínkou, jejíž nedostatek je neodstranitelný a vede nutně k zastavení řízení. Byla by myslitelná konstrukce, dle níž se omezený rozsah hmotněprávní osobnosti přelévá do procesního práva a vytváří omezenou subjektivitu procesní. Tento názor však není udržitelný. Text $\int 19$ o. s. ř. i systematika tohoto předpisu nasvědčují spíše úvaze, že procesní subjektivita není gradována a neexistuje ve více stupních odvíjejících se od stupňủ hmotněprávní subjektivity. Na rozdíl od \ 20 o. s. ř., činícího míru procesní způsobilosti závislou na rozsahu svéprávnosti, totiž $\int 19$ o. s. ř. pracuje s procesní subjektivitou jako s binární hodnotou, kterou určitá entita bud’ nadána je, nebo není. Nepředpokládá tedy diferencování jejího rozsahu a přiznává ji všem osobám s alespoň částečnou hmotněprávní subjektivitou (jakož i některým non-subjektům $\left.{ }^{45}\right) .{ }^{46}$

44 Zvolené řešení v zásadě přejímá i návrh věcného záměru civilního řádu soudního, srovnej konkrétně jeho bod 7.

45 DVOŘÁK, Bohumil. K problematice procesního jednání právnických osob. Právní roz̧hledy, 2016, č. 19 , s. 649.

46 Shodně viz ŠÍNOVÁ, Renáta. In: SVOBODA, Karel, Petr SMOLÍK, Jiří LEVÝ, Renáta ŠÍNOVÁ a kol. Občanský soudni rád: komentár. Praha: C. H. Beck, 2013, s. 58; a ŠÍNOVÁ, Renáta a Marek JURÁŠ. Účastenství v civilním soudním řręení. Praha: Leges, 2015, s. 100-101. 
Rozhodujícím důvodem pro odmítnutí koncepce omezené procesní subjektivity pobočného spolku se však jeví to, že by vedla $\mathrm{k}$ ( $\mathrm{z}$ praktického hlediska velmi nežádoucímu) znejasňování hranice mezi právním posuzováním případu in merito a zkoumáním procesních podmínek. Negativní závěr o způsobilosti pobočného spolku být nositelem práva či povinnosti, o něž je veden spor, by implikoval, že v př́slušném rozsahu pobočný spolek není ani procesním subjektem, a řízení tudíž musí být pro neodstranitelný nedostatek procesní podmínky zastaveno. Usnesení o zastavení řízení přitom ve vztahu k uplatněnému procesnímu nároku nezakládá překážku věci pravomocně rozsouzené ve smyslu 』159a odst. 4 o. s. r..$^{47}$ a nebrání opětovnému projednání téže věci na základě nové žaloby. Naproti tomu pokud by soud rozhodl o určitém právu či povinnosti pobočného spolku meritorně (přijav závěr, že dotčené právo či povinnost spadalo do rozsahu speciální subjektivity dané korporace), bylo by při uplatnění koncepce částečné procesní subjektivity možné napadnout př́islušný rozsudek žalobou pro zmatečnost dovolávající se důvodu dle \ 229 odst. 1 písm. b) o. s. ̌r. s tím, že pobočný spolek, nejsa v daném rozsahu subjektem hmotněprávním, neměl ani způsobilost být účastníkem řízení o dotčeném právu. Prostředek sloužící k prověření fundamentálních deficitů civilního procesu by se tak stal nástrojem revize rozhodnutí po stránce věcné, nebot' by se v ř́izení o žalobě pro zmatečnost musela opětovně zkoumat otázka, zdali se sporné právo (respektive povinnost) nacházelo v mezích hmotněprávní osobnosti pobočného spolku. I s ohledem na právě popsané důsledky pokládám tedy za přesvědčivější závěr, že pobočné spolky, nehledě na př́padnou limitaci své hmotněprávní osobnosti, požívají v občanském soudním ř́izení vždy plné subjektivity procesněprávní.

\section{Omezená právní osobnost „pobočné odborové organizace“}

Konečně se patři věnovat pozornost otázce zvláštního právního režimu odborových organizací. Již v režimu zákona o sdružování občanů vytvářely odborové organizace často organizační jednotky ve smyslu $\int 6$ odst. 2 písm. e) tohoto předpisu nadané právní subjektivitou, nezřídka limitovanou. ${ }^{48} \mathrm{~V}$ režimu zákona č. 89/2012 Sb. se pro zmíněné subjekty zpočátku používalo označení ,pobočné odborové organizace“ (viz \ 3025 a 3046 obč. zák. ve znění účinném do 27. 2. 2017), novelou provedenou zákonem

47 Viz např. usnesení Nejvyššího soudu ze dne 31. 1. 2013, sp. zn. 29 Cdo 1693/2012, ze dne 1. 9. 2016, sp. zn. 28 Cdo 1214/2016, a ze dne 19. 9. 2017, sp. zn. 29 Cdo 5719/2016. Srovnej též DVOŘÁK, Bohumil. In: LAVICKÝ, Petr a kol. Občanský soudni rád (』 1 až 250 l). Praktický komentár. Praha: Wolters Kluwer, 2016, s. 780.

48 Srovnej např. rozsudek Nejvyššího soudu ze dne 31. 8. 2005, sp. zn. 28 Cdo 261/2005. Judikatura těmto subjektům $\mathrm{v}$ některých prrípadech přiznávala dosti specifické vlastnosti, např́íklad právo z mateřské odborové organizace vystoupit (viz rozsudky Nejvyššího soudu ze dne 21. 1. 2009, sp. zn. 28 Cdo 5099/2007, a ze dne 6. 1. 2010, sp. zn. 28 Cdo 3716/2009, či usnesení Nejvyššího soudu ze dne 19. 6. 2018, sp. zn. 28 Cdo 3506/2016). Tyto vývody se však vždy odvijely od obsahu stanov konkrétního odborového svazu vzniklého ve vazbě na poněkud chaotický proces ukončení existence Revolučního odborového hnutí, takže nejsou způsobilé prostého zobecnění a přenosu do poměrů jiných odborových organizací, respektive spolků. 
č. 460/2016 Sb. byl však tento pojem z občanského zákoníku (od 28. 2. 2017) a ze zákona o veřejných rejstrúcích (od 1. 1. 2018) odstraněn. Motivaci této změny osvětluje důvodová zpráva k zákonu č. 460/2016 Sb., z níž vyplývá, že zákonodárce sledoval zvýšení záruk koaliční svobody a zdůraznění teze, že ,i odborová organizace a organizace zaměstnavateli založená jinou odborovou organizací nebo organizaci zaměstnavateli, resp. jejich organizační jednotka s právni subjektivitou, je odborovou organizaci nebo organizaci zamèstnavatelu, nikoliv zuláštni entitou, na niž se primèrenè poǔ̌iji ustanoveni o pobočném spolk.u“. Současně však uskutečněným zásahem do textu předpisů měla zůstat nedotčena „možnost odborových organizaci a organizaci zamèstnavatelu żrizovat si rüzné vnitrni sekece, üseky, oddèleni a organizačni jednotky bez. právni subjektivity" a vyloučena ,by nemèla být ani fakultativni možnost žrídit organizační jednotku s právni subjektivitou, která bude vykazovat obdobné rysy jako pobočný spolek"; „, „p jrimèrená aplikace úpravy pobočného spolku však nebude odborovým organizacím ani organizacím zamèstnavateli vnucována bez možnosti se od ni odchýlit‘.

Zákon č. 460/2016 Sb. ovšem postavení někdejších organizačních složek odborových organizací velmi znejasňuje. Ustanovení \3025 odst. 1 obč. zák., jež zůstalo novelou nedotčeno, nadále ukládá, aby na odborové organizace byla přiměřeně aplikována pravidla o spolcích. Pokud bychom nicméně chtěli vyjít vstříc deklarované intenci zákonodárce a považovat odborové organizace založené jinými odborovými organizacemi za standardní odborové organizace, nikoli pobočné spolky sui generis, zjistili bychom, že postrádáme normativní základ pro konstruování omezené právní osobnosti těchto odborových organizací založených jinými odborovými organizacemi. Pravidlo \228 obč. zák., jež umožňuje limitovat právní subjektivitu, je totiž zakotveno právě toliko pro pobočné spolky. Pakliže se na odvozené odborové organizace pravidla o pobočných spolcích použít nemají, prosadí se obecná norma obsažená v \20 odst. 1, větě druhé, obč. zák., z níž vyplývá generální subjektivita právnických osob. Při přijetí tohoto výkladu by omezení způsobilosti odvozené odborové organizace mít a nabývat práva či povinnosti mělo pouze interní účinky (mohlo by se stát základem pro vyvození sankčních důsledků vůči osobám, které jednaly za odborovou organizaci mimo stanovené hranice), nijak by ale se nemohlo dotknout postavení třetích osob, takže by ani nezakládalo vadu právního jednání, jež by z takto daného rámce právní osobnosti odborové organizace vybočilo. To ostatně koresponduje se skutečností, že se rozsah právní subjektivity zapisuje do veřejného rejstř́k to toliko u pobočného spolku [ $\int 29$ odst. 2 písm. b) zákona o veřejných rejstřících]. Pokud bychom již např́ǐtě pravidla o pobočných spolcích (včetně pravidel rejstř́ikových) nepokládali za použitelná na odborové organizace založené jinými odborovými organizacemi [srovnej též \26 odst. 1 písm. b) zákona o veřejných rejstř́icích ve znění účinném do 31. 12. 2017 a od 1. 1. 2018], vylučoval by princip ochrany dobré víry třetích osob, abychom př́padnému omezení subjektivity, jež by vyplývalo ze stanov odborové organizace, ale nebylo by zapsáno ve veřejném rejstř́ku, přiznávali účinky navenek. 
Naznačené výkladové problémy jsou důsledkem, podle mého názoru iracionální a scestné, snahy vymanit odborové organizace z dosahu právní úpravy spolků a konstruovat je jako zcela svébytný typ soukromoprávní korporace. ${ }^{49}$ Jsem zajedno s názorem Kateřiny Ronovské, že odborové organizace a organizace zaměstnavatelů jsou „v zásadě spolky soukromébo práva (jejich zuláštním druhem)“, 50 a domnívám se, že správnou tendencí by bylo pravidla dopadající na spolky a odborové organizace naopak sbližovat, nebot' spolkovému právu je rovněž vlastní respekt k interní autonomii právnických osob, takže z jeho přiměřeného použití nevyplývá žádné ohrožení pro koaliční svobodu. Pro účely tohoto pojednání nicméně postačí uvést, že je vyloučeno, aby domnělá specifika odborového sdružování šla k tíži třetím osobám. Bude-li tedy existence „odvozených“ odborových organizací s omezenou subjektivitou po účinnosti zákona č. 460/2016 Sb. připuštěna (což předpokládá akceptaci přiměřené použitelnosti alespoň některých pravidel z právní úpravy pobočného spolku na tyto odborové organizace) a má-li být odborová organizace založená jinou odborovou organizací nadána toliko omezenou právní osobností s účinky navenek, musí být dané omezení nejen zakotveno ve stanovách mateřské organizace (jak vyplývá z \228 obč. zák. přiměřeně aplikovaného za použití \3025 odst. 1 obč. zák.), ale musí být rovněž zapsáno ve veřejném rejstř́ku na základě analogického použití \29 odst. 2 písm. b) zákona o veřejných rejstřících, př́padně jako jiná dưležitá skutečnost ve smyslu \25 odst. 1 písm. j) zákona o veřejných rejstř́ících.

\section{Závěr}

Lze tedy shrnout, že omezení právní osobnosti pobočného spolku, jež je zakotveno ve stanovách hlavního spolku a zapsáno ve veřejném rejstř́ku, jak předpokládá \ 228 odst. 1, věta druhá, obč. zák., není pouhým interním opatřením, ale účinkuje i vưči třetím osobám. Nejsou-li při právním jednání za pobočný spolek meze jeho právní subjektivity respektovány, je takové právní jednání podle mého názoru zatíženo absolutní neplatností. Omezená hmotněprávní subjektivita pobočného spolku se ovšem neodráží v omezené procesní subjektivitě, nebot’ i pobočný spolek s limitovanou hmotněprávní osobností je nadán plnou subjektivitou procesní.

Patrně nejkontroverznější téma, jehož se tento text dotýká, je otázka postavení odborových organizací založených jinými odborovými organizacemi. Z hlediska zaměření předmětného článku pokládám za dostatečné vyslovit závěr, že externí účinky případného omezení právní osobnosti daných odborových organizací jsou podmíněny zápisem

49 Srovnání různých náhledů na povahu odborových organizací lze najít v PICHRT, Jan. In: BĚLINA, Miroslav, Ljubomír DRÁPAL a kol. Zákoník práce. Komentár. 2. vyd. Praha: C. H. Beck, 2015, s. 1112-1113; a ŠTEFKO, Martin. Aplikuje se \ 228 odst. 1 ObčZ na základní odborové organizace? Právní roz̧hledy, 2015 , č. 7 , s. 246.

50 RONOVSKÁ, Kateřina. In: LAVICKÝ, Petr a kol. Občanský zákoník I. Obecná část (』 1-654). Komentár. Praha: C. H. Beck, 2014, s. 2306-2307. 
zúženého rozsahu subjektivity do veřejného rejstř́k cím provést analýzu současného statusu někdejších „pobočných odborových organizací“ a intertemporálních účinků zákona č. 460/2016 Sb. (zejména jeho dopadu na již existující odborové organizace). Takový rozbor by však již přesahoval ambice této stati. 